\title{
Montmorillonite KSF Clay Catalyzed Microwave Synthesis of Novel Mannich bases and their Microbial Activity
}

\author{
R. NANDHIKUMAR ${ }^{1,2}$ and K. SUBRAMANI ${ }^{1,3}$ \\ ${ }^{1} R \& D$ center, Bharathiar University Coimbatore, Tamilnadu, India. \\ ${ }^{2}$ Department of Chemistry, The Kavery Engineering college, Salem, Tamilnadu, India. \\ ${ }^{3} P G$ \& Research department of chemistry Islamiah College, vaniyambadi, Tamilnadu, India. \\ ${ }^{*}$ Corresponding author E-Mail: nandhikumar@gmail.com \\ http://dx.doi.org/10.13005/ojc/340328
}

(Received: April 19, 2018; Accepted: May 13, 2018)

\begin{abstract}
Synthesis and characterization of $\mathrm{N}$-(phenyl (thiomorpholino) methyl) acetamide (TBA), $\mathrm{N}$-(phenyl (thiomorpholino) methyl) benzamide (TBB), $\mathrm{N}$-(phenyl (thiomorpholino) methyl) nicotinamide (TBN) and 1-N-(phenyl (thiomorpholino) methyl) carbamide (TBC). The synthesized complexes have been characterized by elemental analysis, TLC, IR, ${ }^{1} \mathrm{H}-\mathrm{NMR},{ }^{13} \mathrm{C}-\mathrm{NMR}$ and Mass Spectroscopy. The final compounds were tested anti-microbial culture study. In the antibacterial and anti-fungal study the compounds $1-N$-(phenyl (thiomorpholino) methyl) carbamide (TBC) shows very good activity against Pseudomonas aeruginosa, Staphylococcus aureus and Escherichia coli and $N$-(phenyl (thiomorpholino) methyl) acetamide (TBA) shows very good activity against Penicillium species, Candida albicans and Aspergillus niger, compare to other Mannich bases. Small reaction time, eco-friendly products, high yield and very good microbial activity are the main advantages of this procedure which makes it more economical than the other conventional methods.
\end{abstract}

Key words: Mannich base, Antibacterial, Antifungal, Microwave.

\section{INTRODUCTION}

Now a days, the development of high economical, and eco-friendly product conversion in microwave synthesis processes is achievement, interest in the research groups. ${ }^{1-8}$ It is well known from the literature. ${ }^{9-11}$ That the compounds containing amide moiety exhibit a wide range of biological activities. ${ }^{12-20}$ In the past few years microwave synthesis methods has increased popularity as a non-conventional procedures for fast organic synthesis methods and many researchers have described accelerated organic reactions. In continuation of our research green chemistry program. ${ }^{21}$ We here in report the microwave assisted synthesis of some Mannich bases like, $\mathrm{N}$-(phenyl (thiomorpholino) methyl) acetamide (TBA) , $N$-(phenyl (thiomorpholino) methyl) benzamide (TBB), $N$-(phenyl (thiomorpholino) methyl) nicotinamide (TBN) and 1-N-(phenyl (thiomorpholino) methyl) carbamide (TBC) catalyzed by eco-friendly Montmorillonite KSF clay. ${ }^{22-26}$ Compounds have been tested by TLC, 
Elemental analysis, IR, ${ }^{1} \mathrm{H}-\mathrm{NMR},{ }^{13} \mathrm{C}-\mathrm{NMR}$ and Mass Spectroscopy, resulting in milder conditions and easy experimental. Over the past few decades, Mannich bases of hetero cyclic particles have been taking the consideration of the synthetic chemists for their widespread range of biological activities reaching from antibacterial ${ }^{27,28}$, antifungal ${ }^{29}$, anticancer ${ }^{30-32}$ antiparkinson ${ }^{33-36}$ to anticonvulsant ${ }^{37-40}$ and antiHIV. ${ }^{41-42}$ Also, 2, 5-disubstituted-1, 3, 4-Oxadiazoles have also been verified to manifest various biological activities like antibacterial, antifungal, anti-inflammator. ${ }^{43-46}$ In this research work, report these methods are very simple and highly efficient, save the time, high purity, good yield, easy procedure for Microwave-irradiation synthesis of some novel Mannich base complexes. The compounds $\mathrm{N}$-(phenyl (thiomorpholino) methyl) acetamide, $\mathrm{N}$-(phenyl (thiomorpholino) methyl) benzamide, $\mathrm{N}$-(phenyl (thiomorpholino) methyl) nicotinamide and $1-N$-(phenyl (thiomorpholino) methyl) carbamide was assumed by elemental analysis and IR, ${ }^{1} \mathrm{H}-\mathrm{NMR},{ }^{13} \mathrm{C}-\mathrm{NMR}$, Mass spectrum values and study the anti-bacterial and fungicidal activity. To the greatest of our information Mannich base reaction catalyzed by eco-friendly, Biodegradable nature Montmorillonite KSF Clay and study the biological activity are unprecedented. This research article is very useful for future research community.

\section{EXPERIMENTAL}

Melting points of the total products were taken in open capillaries and are tested. IR spectra $(\mathrm{KBr})$ were taken on $300 \mathrm{FT}$ IR spectrometer and Bruker (400 MHz FT NMR) spectrometer recorded ${ }^{1} \mathrm{H}-\mathrm{NMR}$ and ${ }^{13} \mathrm{C}-\mathrm{NMR}$ (TMS act as an internal standard), Mass spectrum values was recorded on GC-MS spectrometer-Jeol GC mate spectrometer analyzer. All final products gave satisfactory micro analytical grade report. By TLC methods used to check the final compound's purity.

\section{Synthesis of N-(phenyl (thiomorpholino) methyl) acetamide (TBA)}

Benzaldehyde, Thiomorpholine and acetamide were taken in 1:1:1 mole ratio. Thiomorpholine $(10 \mathrm{~mm})$, acetamide $(10 \mathrm{~mm})$ and then $1 \mathrm{ml}$ of benzaldehyde $(10 \mathrm{~mm})$ was added and kept under microwave radiation at $120{ }^{\circ} \mathrm{C}$ for 1.5 minutes. Then the reaction combination was acidified with concentrated. $\mathrm{HCl}$ and the subordinate layer was disconnected, washing the $\mathrm{H}_{2} \mathrm{O}$ layer by dichloromethane. The organic product layer was dried and, after vacuum distillation, provided the desired Mannich base in sensible yields, (Table 1 and Scheme I). The purity of the compound checked by thin layer chromatography methods.

\section{$\mathrm{N}$-(phenyl (thiomorpholino) methyl) acetamide (TBA)}

(Scheme-I) m.p. of the compound is $165{ }^{\circ} \mathrm{C}$ yield $80 \%$. IR $\left(\mathrm{KBr}, \mathrm{cm}^{-1}\right): 3280(\mathrm{~N}-\mathrm{H}$ str) ), 3155, 3036 (Ar-H str) 2964 (C-H str, $\left.\mathrm{CH}_{3}\right), 2890(\mathrm{C}-\mathrm{H}$, str), 1636 ( $\mathrm{C}=\mathrm{O}$ str), 1598, 1464 (C=C str), 1340, 1313 (C-C str), 1290, 1219 (C-O str), 1180, 1089 (N-C str), 1027 (C-S str). 'H-NMR (DMSO): 9.231$9.216(1 \mathrm{H}, \mathrm{d}), 7.22-7.33(5 \mathrm{H}, \mathrm{m}), 5.14-5.15(1 \mathrm{H}-\mathrm{d})$ 2.71-2.75 (4H, t), 2.69-2.71 (4H, t), $2.25(3 \mathrm{H}, \mathrm{s})$. ${ }^{13} \mathrm{C}-\mathrm{NMR}$ (DMSO):18.12, 28.22, 59.17, 73.33, 126.21, 127.23, 128.34, 148.25, and 165.33. Mass spectra: $\mathrm{m} / \mathrm{z}=250 \mathrm{M}+$.

\section{Synthesis of $\mathrm{N}$-(phenyl (thiomorpholino) methyl) benzamide (TBB) \\ Benzaldehyde, Thiomorpholine and} Benzamide were taken in 1:1:1 mole ratio. Thiomorpholine $(10 \mathrm{~mm})$, acetamide $(10 \mathrm{~mm})$ and then $1 \mathrm{ml}$ of benzaldehyde $(10 \mathrm{~mm})$ was added and kept under microwave radiation at $120^{\circ} \mathrm{C}$ for 1 minute. Then the reaction solution was acidified with concentrated. $\mathrm{HCl}$ and the subordinate layer was disconnected, washing the $\mathrm{H}_{2} \mathrm{O}$ layer by dichloromethane. The organic product layer was dried and, after vacuum distillation, provided the desired Mannich base in sensible yields, (Table 1 and Scheme I). The purity of the compound checked by thin layer chromatography.

\section{$\mathrm{N}$-(phenyl (thiomorpholino) methyl) benzamide (TBB)}

(Scheme-I) m.p. of the compound is $166^{\circ} \mathrm{C}$ yield $79 \%$. IR $\left(\mathrm{KBr}, \mathrm{cm}^{-1}\right)$ : 3276 (N-H str), 3140, 3028 (Ar-H str), 2929, 2827(C-H, str), 1627 (C=O Str), 1597,1464 (C=C str), 1340, 1367 (C-C str), 1313, 1286 (C-O str), 1286 (N-C str), 1220 (C-O str), 1090 (C-S str). ${ }^{1} \mathrm{H}-\mathrm{NMR}$ (DMSO): 9.19-9.20 (1H, d), 7.21-7.77 $(5 \mathrm{H}, \mathrm{m}), 7.02-7.15(5 \mathrm{H}, \mathrm{m}) 5.14-5.15(1 \mathrm{H}, \mathrm{d})$, 2.62-2.71 $(4 \mathrm{H}, \mathrm{t}), 2.44-2.57(4 \mathrm{H}, \mathrm{t}),{ }^{13} \mathrm{C}-\mathrm{NMR}$ (DMSO): 26.25, 59.22, 64.67, 123.74, 125.15, 125.84, 126.87, 128.14, 131.77, 143.74, 148.64 and 165.18. Mass spectra: $\mathrm{m} / \mathrm{z}=312 . \mathrm{M}+$ 


\section{Synthesis of $\mathrm{N}$-(phenyl (thiomorpholino) methyl) nicotinamide (TBN)}

Benzaldehyde, Thiomorpholine and nicotinamide were taken in 1:1:1 mole ratio. Thiomorpholine $(10 \mathrm{~mm})$, acetamide $(10 \mathrm{~mm})$ and then $1 \mathrm{ml}$ of benzaldehyde $(10 \mathrm{~mm})$ was added and kept under microwave radiation at $120^{\circ} \mathrm{C}$ for 1.5 minutes. Then the reaction combination was acidified with concentrated. $\mathrm{HCl}$ and the subordinate layer was disconnected, washing the $\mathrm{H}_{2} \mathrm{O}$ layer by dichloromethane. The organic product layer was dried and, after vacuum distillation, provided the desired Mannich base in sensible yields, (Table 1 and Scheme I). The purity of the compound checked by thin layer chromatography methods.

\section{$\mathrm{N}$-(phenyl (thiomorpholino) methyl) nicotinamide (TBN)}

(Scheme-I)M.Pofthecompoundis $169^{\circ} \mathrm{C}$ yield $76 \%$. IR (KBr, cm$\left.{ }^{-1}\right): 3257$ (N-H str), 3117, 3010 (Ar-H str), 2929, 2873 ( $\mathrm{CH}, \mathrm{str}), 1618$ (C=O Str), 1561, 1525 (C=C str.), 1383, 1365 (C-C str), 1289,(C-O str.), 1219 (N-C str), 1091 (C-S str). ${ }^{1} \mathrm{H}-\mathrm{NMR}$ (DMSO) : 9.185-9.188(1H, d) 8.16-7.66 $(4 \mathrm{H}, \mathrm{m}), 7.27-7.47$ $(5 \mathrm{H}, \mathrm{m}), 5.75-5.84(1 \mathrm{H}, \mathrm{d}), 2.78-2.88(4 \mathrm{H}, \mathrm{t})$, 2.54-2.77 (4H, t). ${ }^{13} \mathrm{C}-\mathrm{NMR}$ (DMSO):26.23, 59.06, $71.93,124.20,125.03,127.05,128.15,132.61$, 138.64, 139.57, 149.93, 157.03 and 165.46. Mass spectra: $\mathrm{m} / \mathrm{z}=313 \mathrm{M}+$.
Synthesis of 1-N-(phenyl (thiomorpholino) methyl) carbamide (TBC)

Benzaldehyde, Thiomorpholine and carbamide (Urea) were taken in 1:1:1 mole ratio. Thiomorpholine $(10 \mathrm{~mm})$, acetamide $(10 \mathrm{~mm})$ and then $1 \mathrm{ml}$ of benzaldehyde $(10 \mathrm{~mm})$ was added and kept under microwave radiation at $120^{\circ} \mathrm{C}$ for 1 minutes. Then the reaction mixturewas acidified with concentrated. $\mathrm{HCl}$ and the subordinate layer was disconnected, washing the $\mathrm{H}_{2} \mathrm{O}$ layer by dichloromethane. The organic product layer was dried and, after vacuum distillation, provided the desired Mannich base in sensible yields, (Table 1 and Scheme I). The purity of the compound checked by thin layer chromatography methods.

\section{1-N-(phenyl (thiomorpholino) methyl) carbamide (TBC)} (Scheme-I) m.p. of the compound is $166{ }^{\circ} \mathrm{C}$ yield $66 \%$. IR ( $\left.\mathrm{KBr}, \mathrm{cm}^{-1}\right): 3324,3318$ $\left(\mathrm{NH}_{2}\right.$ str), 3172, 3106 (Ar-H str), 2979, 2936 (C-H, CH ${ }_{2}$ str) 1619 (C=O Str), 1523, 1465 (C=C str), 1370,1327 (C-C str), 1283, 1263 (C-O str), 1176.1117 (N-C, str), 1027 (C-S, str). ${ }^{1} \mathrm{H}-\mathrm{NMR}$ (DMSO): 9.322-9.328 (1H, d), 7.61$7.87(5 \mathrm{H}, \mathrm{m}), 6.97(2 \mathrm{H}, \mathrm{s}), 5.30-5.31(1 \mathrm{H}, \mathrm{d})$, 2.31-2.35(4H, t), 2.22-2.31 (4H, t). ${ }^{13} \mathrm{C}-\mathrm{NMR}$ (DMSO): 27.01, 58.61, 75.25, 127.61, 129.09, 130.25, 136.04, and 163.04. mass spectra: $\mathrm{m} / \mathrm{z}=251 \mathrm{M}+$.

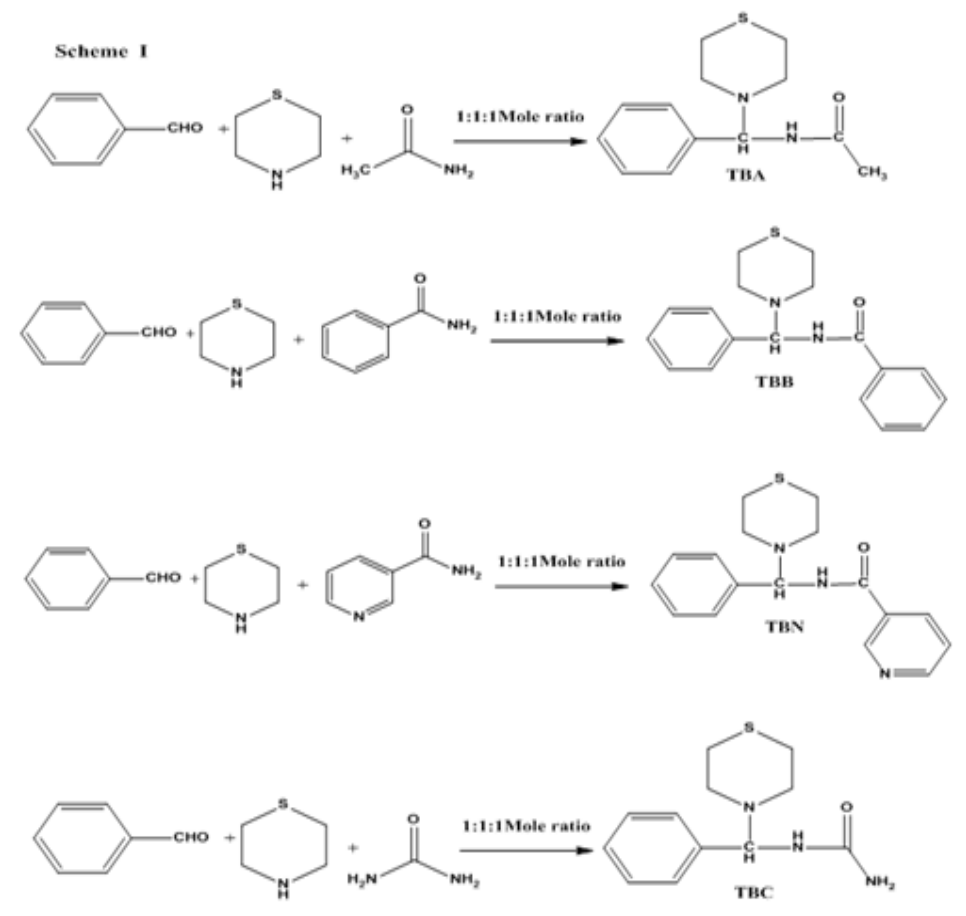




\section{RESULTS AND DISCUSSION}

Mannich base compounds were prepared by Benzaldehyde, Thiomorpholine and acetamide/ Benzamide/nicotinamide/carbamide were taken in 1:1:1 mole ratio. Thiomorpholine, acetamide/ Benzamide/nicotinamide/carbamide and then $1 \mathrm{ml}$ of Benzaldehyde was added and kept under microwave radiation at $120{ }^{\circ} \mathrm{C}$ for $1-1.5 \mathrm{~min}$., Formation of $\mathrm{N}$-(phenyl (thiomorpholino) methyl) acetamide (TBA), $N$-(phenyl (thiomorpholino) methyl) benzamide (TBB), $\mathrm{N}$-(phenyl (thiomorpholino) methyl) nicotinamide (TBN) and 1-N-(phenyl (thiomorpholino) methyl) carbamide (TBC) was confirmed by the presence of $\mathrm{C}-\mathrm{N}$ stretching peaks at $1180,1286,1219 \& 117 \mathrm{~cm}^{-1}$ and $\mathrm{NH}-\mathrm{C}=\mathrm{O}$ stretching peaks at $1636,1627,1619 \& 1618, \mathrm{~cm}^{-1}$ in IR and doublet at $(1 \mathrm{H}) 5.14,5.15,5.75 \& 5.30$ $\mathrm{cm}^{-1}$ for Mannich base group in ${ }^{1} \mathrm{H}-\mathrm{NMR}$ values. ${ }^{1} \mathrm{H}$ NMR spectrum showed a fine triplet at $\delta(4 \mathrm{H}) 2.71$, $2.62,2.78 \& 2.31$ due to thiomorpholin functionality confirmations of their structure were obtained through spectral and analytical data (Table-1). IR and ${ }^{1} \mathrm{H}-\mathrm{NMR}$ spectral data exposed carbonyl absorption band at 1636, 1627, 1618 \& $1619 \mathrm{~cm}^{-1}$ of $\mathrm{NH}-\mathrm{CO}-\mathrm{CH}_{3}, \mathrm{NH}-\mathrm{CO}-\mathrm{C}_{6} \mathrm{H}_{5}, \mathrm{NH}-\mathrm{CO}-\mathrm{C}_{5} \mathrm{H}_{5} \mathrm{~N}$ and $\mathrm{NH}-\mathrm{CO}-\mathrm{NH}_{2}$ group, C-S stretching band at 1027 , $1090,1091 \& 1027 \mathrm{~cm}^{-1}$ aliphatic C-H and aromatic C-H for TBA, Mannich base was obtained at 2964, 3155. Similarly the aliphatic $\mathrm{C}-\mathrm{H}$ and aromatic $\mathrm{C}-\mathrm{H}$ for TBB ,TBN and TBC was obtained at 2929, 3140, 2873,3010 and 2979, $3318 \mathrm{~cm}^{-1}$ group of Mannich base molecule.

Table 1: Physical and analytical data of Mannich bases

\begin{tabular}{|c|c|c|c|c|c|c|c|c|c|c|}
\hline \multirow{2}{*}{$\begin{array}{l}\text { Mannich } \\
\text { Base }\end{array}$} & \multirow[b]{2}{*}{ M.F } & \multirow{2}{*}{$\begin{array}{c}\text { R.T } \\
\text { (Min.)/ } \\
\text { Temp }\end{array}$} & \multirow[b]{2}{*}{ m.p. } & \multirow[b]{2}{*}{$\mathrm{Rf}$} & \multirow[b]{2}{*}{ Yield } & \multicolumn{5}{|c|}{ Found (Calculated)\% } \\
\hline & & & & & & C & $\mathrm{H}$ & $\mathrm{N}$ & O & $S$ \\
\hline \multirow[t]{2}{*}{ TBA } & \multirow{2}{*}{$\mathrm{C}_{13} \mathrm{H}_{18} \mathrm{~N}_{2} \mathrm{OS}$} & $1.5 /$ & \multirow[t]{2}{*}{$165^{\circ} \mathrm{C}$} & \multirow[t]{2}{*}{0.5} & \multirow[t]{2}{*}{$80(\%)$} & 62.12 & 6.95 & 11.02 & 6.1 & 12.62 \\
\hline & & $120^{\circ} \mathrm{C}$ & & & & (62.27 & 7.15 & 11.15 & 6.29 & 12.71) \\
\hline \multirow[t]{2}{*}{ TBB } & \multirow[t]{2}{*}{$\mathrm{C}_{18} \mathrm{H}_{20} \mathrm{~N}_{2} \mathrm{OS}$} & $1.0 /$ & \multirow[t]{2}{*}{$166^{\circ} \mathrm{C}$} & \multirow[t]{2}{*}{0.6} & \multirow[t]{2}{*}{$79(\%)$} & 68.9 & 6.25 & 8.86 & 5.02 & 10.05 \\
\hline & & $120^{\circ} \mathrm{C}$ & & & & (69.10 & 6.35 & 8.95 & 5.1 & 10.22) \\
\hline \multirow[t]{2}{*}{ TBN } & \multirow{2}{*}{$\mathrm{C}_{17} \mathrm{H}_{19} \mathrm{~N}_{3} \mathrm{OS}_{2}$} & $1.5 / 1$ & \multirow[t]{2}{*}{$169^{\circ} \mathrm{C}$} & \multirow[t]{2}{*}{0.5} & \multirow[t]{2}{*}{$76(\%)$} & 64.9 & 6.02 & 13.21 & 5.01 & 10.12 \\
\hline & & $20^{\circ} \mathrm{C}$ & & & & $(65.10$ & 6.1 & 13.31 & 5.08 & 10.22) \\
\hline \multirow[t]{2}{*}{ TBC } & \multirow{2}{*}{$\mathrm{C}_{12} \mathrm{H}_{17} \mathrm{~N}_{2} \mathrm{OS}$} & $1.0 /$ & \multirow[t]{2}{*}{$1710 \mathrm{C}$} & \multirow[t]{2}{*}{0.6} & \multirow[t]{2}{*}{$72(\%)$} & 57.14 & 6.63 & 16.57 & 6.26 & 12.62 \\
\hline & & $120^{\circ} \mathrm{C}$ & & & & $(57.24$ & 6.72 & 16.68 & 6.35 & 12.71) \\
\hline
\end{tabular}

${ }^{1} \mathrm{H}-\mathrm{NMR}$ spectrum showed a fine singlet at $\delta(3 \mathrm{H}) 2.25,6.97$ due to amide functionality confirmations of their structure were obtained through spectral and analytical data (physical and analytical data are given in Table-1. ${ }^{1} \mathrm{H}-\mathrm{NMR}$ spectral values showed a fine multiple at $(5 \mathrm{H})$ $7.22,7.02,7.27$ and 7.61 due to aromatic cyclic functionality confirmations of their structure. Mass spectrum also supported the proposed structure by viewing molecular ion peak at $\mathrm{m} / \mathrm{z}=250,312,313$ $\& 251 \mathrm{M}+$.

\section{Antibacterial activity}

Novel synthesized Mannich base compounds are screened for their antibacterial activity in vitro against the species of Escherichia coli (Gram negative), Pseudomonas aeruginosa
(Gram negative) and Staphylococcus aureus (Gram positive) by agar well disk diffusion method. Ciprofloxacin is used as a standard drug and the outcomes are shown in Table-2. In the antibacterial study the compounds $1-\mathrm{N}$-(phenyl (thiomorpholino) methyl) carbamide (TBC) shows very high activity against $P$ seudomonas aeruginosa, Staphylococcus aureus and Escherichia coli compare to other Mannich bases (Fig.1, Fig 2, Fig. 3 and Fig. 4 ).

\section{Anti-fungal activity}

Newly synthesized Mannich base compounds are screened for their antifungal activity in vitro against the species of Penicillium species, Candida albicans and Aspergillus niger, using agar well disk diffusion method. All Mannich base compounds are dissolved in DMSO. 
Table 2: Antibacterial activity \& Antifungal activity for Mannich bases

\begin{tabular}{lcccccc}
\hline & \multicolumn{3}{c}{ Activity $(\mathrm{mm})$ Antibacterial } & \multicolumn{3}{c}{ Antifungal activity $(\mathrm{mm})$} \\
\cline { 2 - 7 } No. & E. coli & S. aureus & P. aeruginosa & P. species & A. niger & C. albicans \\
\hline TBA & 6 & 9 & 6 & 9 & 7 & 6 \\
TBB & 5 & 4 & 4 & 4 & - & - \\
TBN & 11 & 7 & 4 & - & - & - \\
TBC & 13 & 10 & 9 & 7 & - & - \\
\hline
\end{tabular}
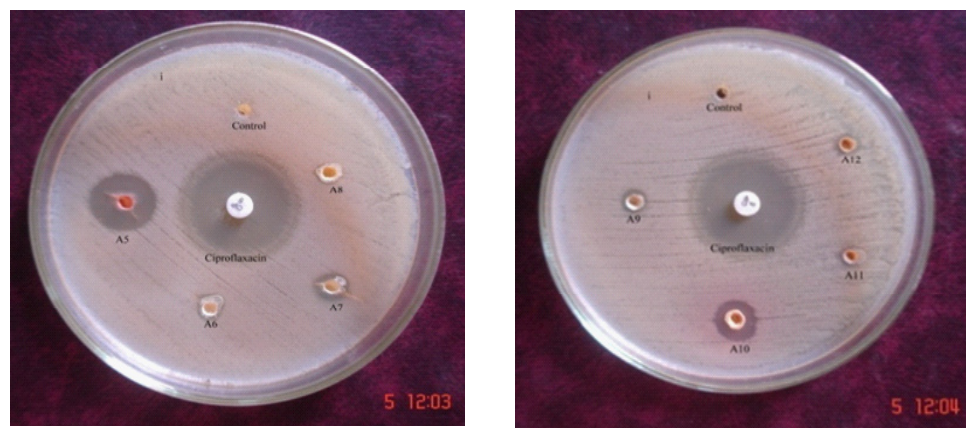

Fig. 1. Antibacterial Activity of TBA, TBB, TBN and TBC (Pseudomonas aeruginosa)
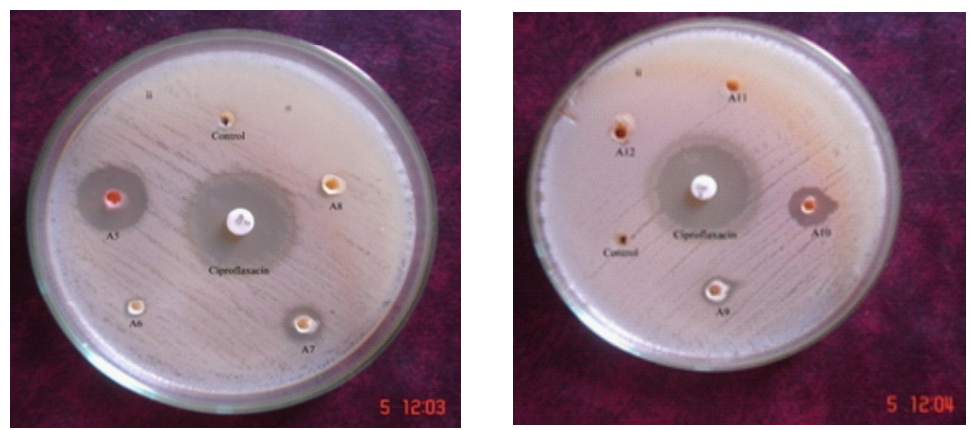

Fig. 2. Antibacterial Activity of TBA, TBB, TBN and TBC (Staphylococcus aures)
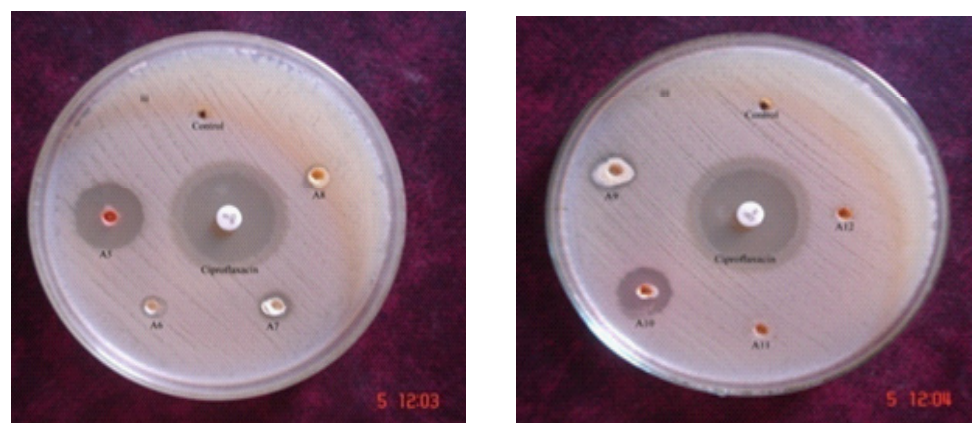

Fig. 3. Antibacterial Activity of TBA, TBB, TBN and TBC (Escherichia coli) 
Amphotericin-B is used as a standard and the outcomes are shown in Table-2, and Fig. 4. In the anti-fungal study the compounds $\mathrm{N}$-(phenyl (thiomorpholino) methyl) acetamide (TBA) shows very good activity against Penicillium species, Candida albicans and Aspergillus niger, compare to other Mannich bases. Finally, this research paper very useful for future research scholar, scientist and new innovators because it is solvent free and single step product finding methods, and product yield is very high and take less reaction time.

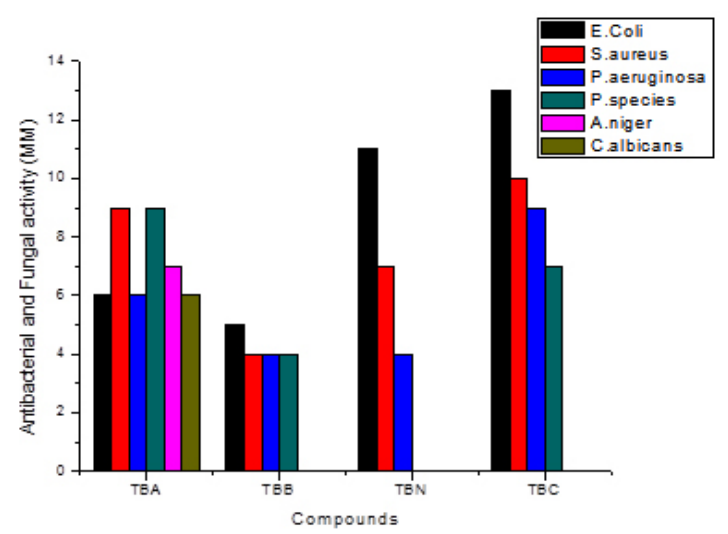

Fig. 4. Comparison of Antibacterial and Antifungal activity for Mannich Bases

\section{CONCLUSION}

Microwave assisted synthesis of Benzaldehyde, Thiomorpholine and acetamide/ Benzamide/nicotinamide/carbamide (Urea) were taken in 1:1:1 mole ratio, give good yields of Mannich bases like, $\mathrm{N}$-(phenyl (thiomorpholino) methyl) acetamide (TBA), $N$-(phenyl (thiomorpholino) methyl) benzamide (TBB), $N$-(phenyl (thiomorpholino) methyl) nicotinamide (TBN) and 1-N-(phenyl (thiomorpholino) methyl) carbamide (TBC). Total compounds are lively against all the verified bacterial and fungal strains. Compound TBA, TBB, TBN and TBC (Mannich base) are medium or more active against antibacterial and fungal strains for standard drug for antibacterial activity. In the antibacterial and anti-fungal study the compounds $N$-(phenyl (thiomorpholino) methyl) acetamide (TBA) shows very good activity against $P$ seudomonas aeruginosa, Staphylococcus aureus and Escherichia coliand 1- $N$ (phenyl (thiomorpholino) methyl) carbamide (TBC) shows very good activity against Penicillium species, Candida albicans and Aspergillus niger, compare to other Mannich bases. The process has more benefit, for example, it is a green chemistry method, the simple handling method, the less reaction time, simple experimental setup enough, and use of a cheap and eco-friendly nature catalyst.

\section{ACKNOWLEDGEMENT}

One of the author thanks to Chairman, Director and Principal of The Kavery Engineering College, Taminadu, India and Dr. G. Sarawathi, HOD of chemistry Government Engineering College Bargur, Tamilnadu, India for their encouragement and providing necessary research facilities.

\section{REFERENCES}

1. Poonam Gupta.; Jitendra, K.; Gupta.; Halve, A, K. IJPSR., 2015, 6(6), 22912310.

2. Rajni Ratti. Advances in Chemistry., 2014, 16, 729-842.

3. Kullampalayam Krishnasamy Sivakumar.; Aiyalu Rajasekaran Palaniappan.; Senthilkumar Prasad.; Wattamwar,P.; Bioorg \& Med Chem Let., 2014, 24(13), 2940-2944.

4. Vatsal, M.; Patel and Navin, B.; Patel. IJPSR., 2017, 8(9), 4021- 4033.

5. S. Ravichandran, Int. J. ChemTech Res., 2010, 2(4).

6. Saravanan, P.; Anandakumar, S. Int. J. Curr. Microbiol. App. Sci., 2013, 2(2), 76-79.
7. Sathya,D.; Senthil Kumaran,J.; Priya, S.; Jayachandramani, N.; Mahalakshmi, S.; Amali Roseline Emelda. Int. J. Chem Tech Res., 2011, 3(1).

8. Po-Jung J. Huang.; Youssef,D.;Stanley Cameron,T.; Amitabh Jhaa. ARKIVOC., 2008, (xvi) 165-177.

9. Maliki Reddy Dastagiri Reddy.; Aluru Raghavendra Guru Prasad.; Yadati Narasimha Spoorthy:; Lakshmana Rao Krishna Rao Ravindranath.; J App Pharm., 2013, 5(3), 781-793.

10. Suman Bala.; Neha Sharma.; Anu Kajal.; Sunil Kamboj.; Vipin Saini.; Int $J$ of Med Chem., 2014, 15, 191072. 
11. Dongamanti Ashok.; Srinivas Gundu.; Vikas Kumar Aamate.; Mohan Gandhi Devulapally. Molecular Diversity., 2018, 22(1), 57-70.

12. Sathya, D.; Senthil Kumaran,J.; Jayachandramani, N.; Amali Roseline Emelda, R. J. P. B. C., 2012, 3, 905.

13. G. Govindu.; P. Raveendra Reddy.; D. Rajesh and L. K. Ravindranath, Der Pharma Chemica., 2015, 7 (10), 362-371.

14. Evgeny V. Buravlev.; Oksana G. Shevchenko.; Aleksei A.Anisimov.; Kyrill YuSuponitsky, Eur $J$ of Med Chem., 2018, 152(25), 10-20.

15. Rathakrishnan, S.; , Abdul Jameela ,A.; Syed Ali Padusha, M. Int Jof Scie and Res Pub., 2014, 4, 7.

16. Xiao-hua Cai .; Bing Xie. ARKIVOC., 2013, (i), 264-293.

17. Nagham Mahmood Aljamali .; Ahmed Adnan Abdul Hussein.; J.Bio. Innov., 2017, 6(1), 91-99.

18. A. Idhayadhulla,A.; Surendra Kumar, R.; Jamal Abdul Nasser, A.; Aseer Manilal. J. Chem. Pharm. Res., 2011, 3(4), 904-911.

19. Balakrishnan , A.; Sankar, A. Int $J$ of Sci and Res Pub., 2016, 6, 11.

20. Balakrishnan, A.; Sankar, A. IOSR J of App Chem., 2016, 9(11), 65-69.

21. Mazaahir Kidwai.; Ruby Thakur.; Richa Mohan. Acta Chim. Slov., 2005, 52, 88-92.

22. Omid marvi.; Maryam Talakoubi. Orient. J. Chem., 2016, 32(1), 359-365.

23. Davood Habibi and Omid Marvi. ARKIVOC ., 2006, (xiii) 8-15.

24. Davood.; Habibi .;Omid Marvi. Catalysis Comm., 2007, 8(2), 127-130.

24. Gopalpur Nagendrappa. App Clay Sci., 2011, 53(2), 106-138.

25. Marvi.; Omid.; Giahi.; Masoud. Bull of the Kore Chem Soc., 2009, 30(12) 2918-2920.

26. Yogesh, S.; Parab.; Rikhil,V.; Shah and Sanjeev, R..; Shukla. Curr Chem Lett., 2012, 81-90.

27. Meera Moydeen, A.; Syed Ali Padusha, M.; Hany El-Hamsharya.; Mohamed, H.; El-Newehya and Salem, S.; Al-deyaba.; Der Chemica Sinica., 2013, 4(3),93-99.

28. Amali Roseline Emelda.; jayachandramani, N.; and Ravichandran, S.; Asian J of Chem., 2008, 20(4), 2485-2490.

29. Teodoro S. Kaufman.; Braz, J. Chem. Soc. 2015, 26, 6.

30. Suman Bala.; Neha Sharma.; Anu Kajal.; Sunil Kamboj.; and Vipin Saini. Int J of Med Chem.
2014, 15, 191072.

31. Bhupendra MistrY; Young-Soo Keum.; Rafi Noorzai.;Enkhtaivan Gansukh.;Doo Hwan Kim.; J of the Irani Chem Soc., 2016, 13(3), 531-539.

32. Bhupendra Mistry.;Rahul V.Patel.;Young-Soo Keum.; Doo HwanKim. Saudi J of Bio Sci., 2017, 24(1), 36-44.

33. Gigani Yaseen and Jadhav Sudhakar. Int $J$ of Phar and Bio Sc., 2010, 4.

34. Sekar Vinoth Kumar .; Mohan Raj Subramanian.; Santhosh Kumar Chinnaiyan. $J$ of Young Phar., 2013(5), 154-159.

35. A. Rizwan Sulthanaa, A.; Syed Ali Padushab, M and Abdul Jameela, A. I J S C., 2012, 5(1), 55-58.

36. SekarVinoth Kumar.; Mohan Raj Subramanian.; and Santhosh Kumar Chinnaiyan. J Young Pharm., 2013, 5(4), 154-159.

37. Anna Czopek.; Hanna Byrtus.; Agnieszka Zagórska.; Agata Siwek.;Grzegorz Kazek.; Marek Bednarski.; Jacek Sapa.; Maciej Pawłowski. Pharma cological Reports., 2016, 886-893.

38. RajaEmail author, A.S.; Pandeya, S.N.; Panda, S.S.; Stables, J.P. Pharmaceutical Chemistry. Journal., 2007, 41(6), 302-307.

39. Surendra, N.; Pandeya and Neha Rajput. Der Pharmacia Lettre., 2012, 4(3), 938-946.

40. Krzysztof Kaminski.; Jolanta Obniskalwona.; Chlebek Beata Wiklik.; Sabina Rzepka.; Bioorg \& Med Chem., 2013, 21(1), 6821-6830.

41. M. Sreedevi Meesaraganda, M.; Raghavendra Guru Prasad Aluru.; Spoorthy Y. Narasimha.; Ravindranath, L.; Krishna Rao. J App Pharm., 2013, 5( 3), 805-811.

42. Dharmarajan Sriram.; Debjani Banerjee.; Perumal Yogeeswari. J of Enzyme Inhibition and Med Chem., 2009, 24, 1.

42. Olcay Bekircan and Hakan Bektas . Molecules., 2008, 13, 2126-2135.

43. Kalyani, G.; Srinivas Bethi .; Sastry, K.; Vijaya Kuchana. Inter J of Pharma and Clinical Res., 2017, 9(7), 515-520.

44. Alexandra Tomaa.; Denisa Hapau.; Mara Naghib.; Laurian Vlasec.; Cristina Mogoùand.; Valentin Zahariaa.; Studia Ubb Chemia, 2012, 2, 93 - 104.

45. Chandravadivelu.; Gopi.; Magharla.; Dasaratha.; Dhanaraju.; Beni-Suef. Uni J of Basic and App Sci., 2018, 22.

46. Bele, D.S and Singhvi, I. IJRPC., 2011, 1(4). 